
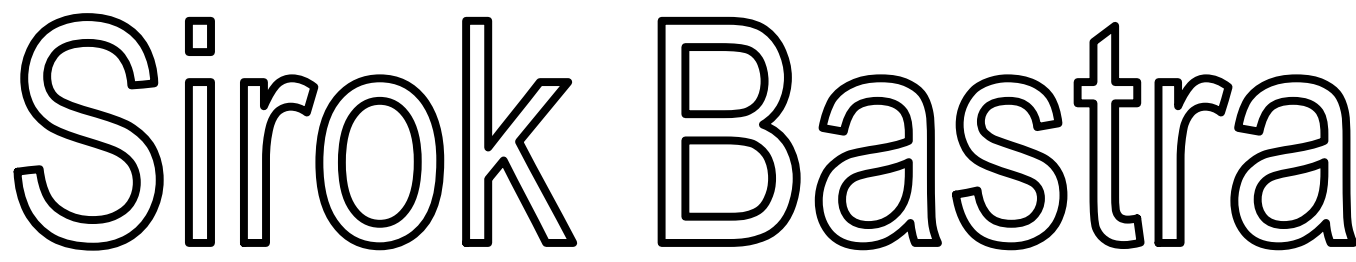

J URNAL ILMIAH KEBAHASAAN DAN KESASTRAAN

\begin{tabular}{|c|c|c|c|c|c|}
\hline $\begin{array}{c}\text { Sirok Bastra } \\
\text { Jurnal Kebahasaan dan } \\
\text { Kesastraan }\end{array}$ & Volume 5 & Nomor 2 & $\begin{array}{c}\text { Hlm. } \\
101-196\end{array}$ & $\begin{array}{c}\text { Pangkalpinang, } \\
\text { Desember } \\
2017\end{array}$ & $\begin{array}{c}\text { ISSN } \\
2354-7200\end{array}$ \\
\hline
\end{tabular}

KANTOR BAHASA KEPULAUAN BANGKA BELITUNG 


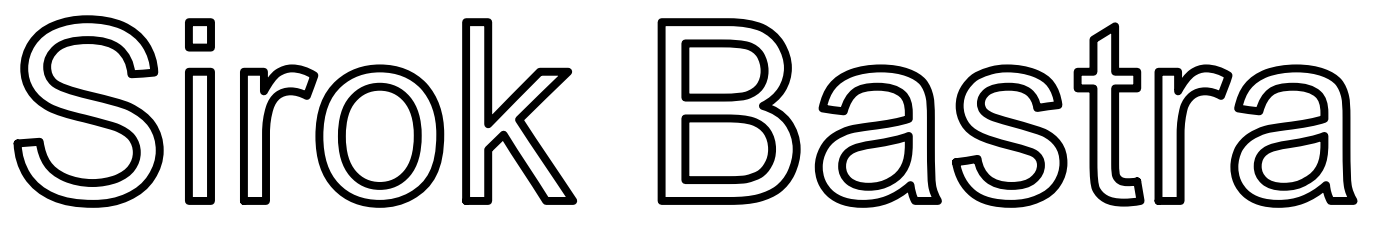

\section{J URNAL ILMIAH KEBAHASAAN DAN KESASTRAAN}

Jurnal ini merupakan wadah informasi kebahasan, kesastraan, dan pengajarannya yang memuat hasil penelitian, studi kepustakaan, dan tulisan ilmiah bidang kebahasan dan kesastraan serta pengajarannya. Sirok Bastra terbit dua kali setahun, yakni Juni dan Desember, serta terbit sejak Juni 2013.

\section{Penanggung Jawab}

Kepala Kantor Bahasa Kepulauan Bangka Belitung

Drs. Hidayatul Astar, M.Hum.

\section{Mitra Bestari}

Prof. Dr. Agus Nuryatin, M.Hum. (Bidang Sastra dan Pengajarannya)

Prof. Amrin Saragih, Ph.D., M.A. (Bidang Bahasa dan Pengajarannya)

Dr. Felicia Nuradi Utorodewo, M.Hum. (Bidang Bahasa dan Pengajarannya)

Dr. Pujiharto, M.Hum. (Bidang Sastra dan Pengajarannya)

\section{Pemimpin Redaksi}

Rahmat Muhidin, S.S.

\section{Penyunting}

Dr. Asyraf Suryadin, M.Pd.

Prima Hariyanto, S.Hum.

Sarman, S.Pd.

\section{Perancang Sampul}

Feri Pristiawan, S.S.

\section{Pengatak}

Dewi Septi Kurniawati, S.Kom.

\section{Kesekretariatan \\ Ria Anggraini, S.E. Juliati, S.E.}

\section{Alamat Redaksi dan Penerbit}

Kantor Bahasa Kepulauan Bangka Belitung

Jalan Letkol Saleh Ode No. 412, Kota Pangkalpinang, Prov. Kepulauan Bangka Belitung Telepon (0717) 438455, Faksimile(0717)9103317, Pos-el: sirokbastra@gmail.com, sirokbastra@kemdikbud.go.id

Pemuatan suatu tulisan dalam jurnal ini tidak berarti redaksi menyetujui isi tulisan tersebut. Isi tulisan menjadi tanggung jawab penulis. Tulisan telah ditinjau dan diulas oleh mitra bestari. Setiap karangan dalam jurnal ini dapat diperbanyak setelah mendapat izin tertulis dari penulis, redaksi, dan penerbit. 


\section{PENGANTAR}

Puji syukur ke hadirat Pemilik dan Pencipta semesta ini yang memiliki kuasa atas diri-Nya sendiri. Dialah Tuhan Yang Maha Esa yang telah memberikan rahmat dan hidayah-Nya sehingga Volume 5 Nomor 2 Jurnal Sirok Bastra Tahun 2017 dapat terbit tepat pada waktunya.

Pada edisi ini dimuat sepuluh tulisan, yakni lima tulisan kebahasaan, empat tulisan kesastraan, dan satu tulisan pengajaran sastra.

Dalam penelitiannya, Hotnida Novita Sary menganalisis iklan komersial Meikarta yang telah membuat perusahaan tersebut berhasil mencatatkan penjualan yang fantastis. Penelitian yang dilakukannya menggunakan pisau bedah analisis wacana kritis Fairclough (1989). Iklan Meikarta membandingkan kesuperioritasan mereka dibandingkan kota metropolitan lain, seperti Jakarta. Meikarta juga menanamkan ideologi bagi masyarakat kota besar bahwa kota metropolitan saat ini sudah tidak aman, kotor, dan macet.

Dalam makalahnya, Hidayatul Astar mengkaji realisasi konsep bahasa Indonesia ke dalam bahasa Rejang. Menurutnya, masyarakat Rejang tidak memiliki konsep (kata atau istilah) yang cukup untuk mewakili pikiran dan perasaan tertentu ketika berkomunikasi, terutama yang terkait dengan konsep kehidupan modern atau yang sesuai dengan perkembangan zaman. Karena itu, bahasa Rejang perlu memungut atau mengambil dari bahasa lain, khususnya dari bahasa Indonesia. Realisasi bentuk konsep yang ditemukan adalah realisasi tanpa perubahan dan realisasi dengan perubahan. Berdasarkan data, realisasi perubahan dalam sebuah konsep dapat satu kali atau lebih. Realisasi perubahan itu berupa penghilangan, penggantian, dan penambahan bunyi vokal atau konsonan tertentu pada posisi tertentu. Terjadinya perubahan realisasi bunyi bahasa Indonsia ke dalam bahasa Rejang disebabkan oleh keinginan penutur bahasa Rejang dan adaptasi terhadap bunyi yang sudah ada.

Dalam kajiannya, Mardi Nugroho membahas pembentukan kata dalam bahasa Talondo di Sulawesi Barat. Hasil analisis data menunjukkan bahwa ada tiga macam cara pembentukan kata dalam bahasa Talondo, yaitu afiksasi, reduplikasi, dan pemajemukan. Pembentukan kata dengan afiksasi terdiri atas pembentukan kata dengan prefiksasi, konfiksasi, infiksasi, dan sufiksasi. Pembentukan kata dengan reduplikasi terdiri atas reduplikasi murni, reduplikasi sebagian, dan reduplikasi yang berkombinasi dengan afiksasi.

Dalam kajiannya, Muhammad Fadely membahas makna dan bentuk pemakaian eufemisme dan disfemisme dalam feature karya Ruslan Ismail Mage yang bermanfaat bagi pengajaran bahasa Indonesia dan pengembangan bahasa di media massa cetak. Hasil analisis menunjukkan bahwa pemakaian eufemisme lebih banyak daripada pemakaian disfemisme. Berdasarkan simpulan tersebut, peneliti menyarankan bahwa dalam menyampaikan suatu informasi kepada khalayak umum hindari tulisan-tulisan yang dapat mengaburkan dan tidak terus terang demi maksud-maksud tertentu.

Dalam kajiannya, Asri Soraya Afsari membahas karakteristik bahasa yang digunakan dalam iklan komersial ponsel yang berada di Kota Bandung. Hasil penelitian menunjukkan bahwa bentuk dan fungsi bahasa yang digunakan dalam iklan ponsel di Kota Bandung berupa penulisan huruf kapital secara keseluruhan dan penulisan huruf kapital pada awal kata. Bahasa iklan ponsel memiliki fungsi informatif dan konatif (persuatif).

Dalam tulisannya, Erwin Wibowo mendeskripsikan makna semiotik budaya Lampung yang ada di dalam antologi Kitab Cerpen Perempuan di Rumah Panggung. Hasil penelitian mengungkapkan ikon, indeks, dan simbol budaya Lampung melalui pendekatan semiotik yang dipakai dalam Kitab Cerpen Perempuan di Rumah Panggung karya Isbedy Stiawan ZS dan memberi deskripsi tentang ikon, indeks, dan simbol tesebut.

Dalam penelitiannya, Prima Hariyanto membahas penokohan dalam Kitab Omong Kosong yang mengambil cerita epos Ramayana. Dalam novel ini, pengarang mengubah pola cerita. Tokoh sentral dalam cerita ini bukan lagi Rama dan Sinta, tetapi Maneka dan Satya. Ceritanya bukan lagi kisah cinta Rama dan Sinta, tetapi kisah perjalanan Maneka dan Satya dalam mencari Kitab Omong Kosong ciptaan Hanoman. Tokoh Rama tidak lagi diceritakan sebagai kesatria yang baik, tetapi sebagai raja yang membawa bencana bagi rakyat di muka bumi.

Dalam kajiannya, Dian Anggraini mengkaji intertekstual lima puisi Indonesia yang berisi tentang sosok wanita yang disebut ibu, yaitu "Ibu Dehulu" (Amir Hamzah), "Ibu” (Chairil Anwar), "Sajak Ibu” (Wiji Thukul), 
"Bunda Air Mata" (Emha Ainun Najib"), dan "Ibu” (K.H. Mustofa Bisri). Hasil telaah itu membuktikan bahwa kelima puisi tersebut merupakan mosaik, kutipan-kutipan, penyerapan, dan perspektif yang beragam terhadap sosok ibu. Setiap penyair mengungkapkan sisi ibu dari pandangan yang berbeda.

Dalam kajiannya, Yuliadi M.R. membahas makna ground dalam cerpen "Uak dan Burung Gagak" dengan pendekatan objektif melalui teori semiotik Pierce. Berdasarkan kajian, terungkap bahwa makna ground dalam cerpen Uak dan Burung Gagak, yaitu ground qualisign berupa warna hitam, sinsign berupa suara koakkoak, dan legisign berupa perilaku mengitari rumah.

Dalam tulisannya, Abdul Azis dan Hajrah membahas dongeng sebagai bahan pembelajaran di sekolah dasar. Data penelitian ini adalah dongeng Cerita Si Jingkiriq, I Kukang, Nenek Pakande, La Dana dan Kerbaunya, dan Puang Tedong. Hasil analisis data dan temuan menunjukkan bahwa rata-rata penilaian responden untuk dongeng sebesar 3,75 (kategori layak dijadikan bahan ajar). Bahan ajar yang dapat digunakan untuk tingkat SD adalah dongeng yang isinya sesuai dengan karakteristik, pengalaman, dan kebutuhan siswa.

Kami mengucapkan terima kasih kepada para penulis yang telah bersedia menerbitkan karya mereka pada edisi ini. Para penulis merupakan peneliti, pakar, dosen, dan mahasiswa dari berbagai perguruan tinggi dan instansi. Terima kasih juga kami sampaikan kepada para mitra bestari kami yang telah memberi ulasan terhadap tulisan-tulisan yang masuk ke redaksi.

Demi memenuhi keberagaman isi dan penulis, Sirok Bastra membuka kesempatan bagi para peneliti dan penulis menyampaikan hasil penelitian dan pemikiran mutakhir dalam bidang kebahasaan, kesastraan, dan pengajarannya. 


\section{UCAPAN TERIMA KASIH UNTUK MITRA BESTARI}

Redaksi Sirok Bastra mengucapkan terima kasih kepada para mitra bestari yang telah meninjau, menimbang, dan mengulas makalah-makalah yang diterbitkan dalam Sirok Bastra Volume 5 Nomor 2, edisi Desember 2017, yakni

Prof. Dr. Agus Nuryatin, M.Hum.

Bidang Sastra dan Pengajarannya

Universitas Negeri Semarang

Semarang, Jawa Tengah

Prof. Amrin Saragih, Ph.D., M.A.

Bidang Bahasa dan Pengajarannya

Universitas Negeri Medan

Medan, Sumatra Utara

Dr. Felicia Nuradi Utorodewo, M.Hum.

Bidang Bahasa dan Pengajarannya

Universitas Indonesia

Depok, Jawa Barat

\section{Dr. Pujiharto, M.Hum.}

Bidang Sastra dan Pengajarannya

Universitas Gadjah Mada

Yogyakarta, Daerah Istimewa Yogyakarta 


\section{DAFTAR ISI}

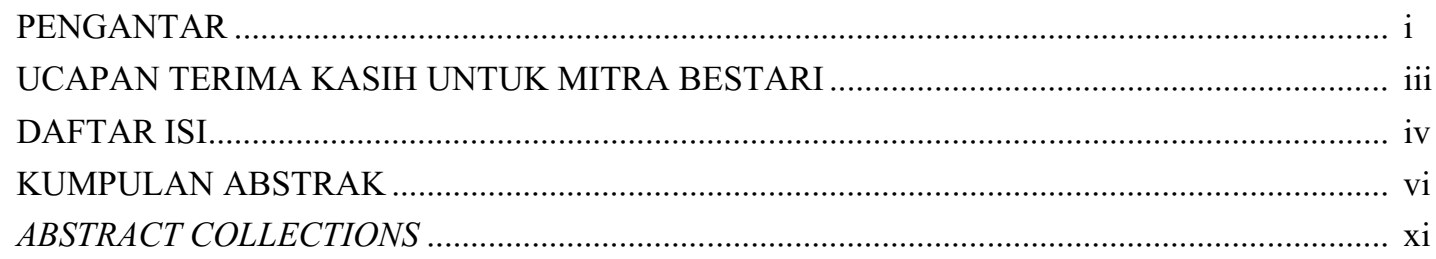

ANALISIS WACANA KRITIS IKLAN KOMERSIAL MEIKARTA

(Critical Discourse Analysis of Meikarta Commercial Advertising)

Hotnida Novita Sary $101-111$

REALISASI KONSEP BAHASA INDONESIA DALAM BAHASA REJANG

(Realization of Indonesian Concept Into Rejang Language)

Hidayatul Astar. $113-121$

PEMBENTUKAN KATA DALAM BAHASA TALONDO

(The Word Formation in Talondo Language)

Mardi Nugroho $123-129$

EUFEMISME DAN DISFEMISME PADA FEATURE-FEATURE KARYA RUSLAN ISMAIL MAGE

(Euphemism and Disphemism in The Features by Ruslan Ismail Mage)

Muhammad Fadely $131-139$

KARAKTERISTIK PENGGUNAAN BAHASA DALAM IKLAN PONSEL DI KOTA BANDUNG

(The Characteristic of Language Usage on Mobile Phone Advertisement in Bandung) Asri Soraya Afsari $141-151$

SIMBOL BUDAYA LAMPUNG DALAM KITAB CERPEN PEREMPUAN DI RUMAH PANGGUNG KARYA ISBEDY STIAWAN Z.S.: KAJIAN SEMIOTIKA

(Lampung Cultural Symbols in Kitab Cerpen Perempuan di Rumah Panggung by Isbedy Stiawan Z.S.: a Semiotic Analysis)

Erwin Wibowo $153-161$

PENOKOHAN DALAM KITAB OMONG KOSONG KARYA SENO GUMIRA AJIDARMA (Characterization in Kitab Omong Kosong by Seno Gumira Ajidarma)

Prima Hariyanto $163-169$

WANITA ISTIMEWA: KAJIAN INTERTEKSTUAL TERHADAP PUISI-PUISI TENTANG IBU

(Special Woman: Intertextual Study of Poems About Mother) 
BURUNG GAGAK SEBUAH TANDA: MAKNA GROUND DALAM CERPEN UAK DAN BURUNG GAGAK

(Brids Crow A Sign: Ground Meaning in Uak and Burung Gagak Short Story)

Yuliadi M.R.

DONGENG SEBAGAI BAHAN PEMBELAJARAN BAHASA INDONESIA DI SEKOLAH

DASAR

(Folktale as Indonesian Language Learning Material in Elementary School)

Abdul Azis dan Hajrah

$191-196$ 


\title{
PEMBENTUKAN KATA DALAM BAHASA TALONDO
}

\author{
The Word Formation in Talondo Language
}

\author{
Mardi Nugroho \\ Badan Pengembangan dan Pembinaan Bahasa \\ JalanDaksinapati Barat IV, Rawamangun, Jakarta Timur \\ Pos-el: mardinugroho16@gmail.com
}

(diterima 15 Agustus 2017, disetujui 4 September 2017, revisi terakhir 8 Desember 2017)

\begin{abstract}
Abstrak
Di Mamuju, Sulawesi Barat terdapat bahasa Talondo. Jumlah penuturnya sangat minim, yaitu 400 orang (Lewis, 2009:448). Tingkat vitalitasnya ialah mengalami kemunduran (Aritonang, 2014). Bahasa yang jumlah penuturnya sangat minim dan tingkat vitalitasnya mengalami kemunduran selayaknya diprioritaskan untuk didokumentasikan. Salah satu langkah dalam mendokumentasikan suatu bahasa ialah menyusun strukturnya. Penelitian ini berusaha menemukan bagian kecil dari struktur bahasa Talondo, yaitu pembentukan kata. Pengumpulan data dilakukan dengan teknik wawancara, teknik rekam, serta teknik simak dan catat. Analisis data dilakukan dengan metode distribusional (dengan teknik urai unsur terkecil, teknik pergantian, dan teknik ekspansi) serta metode padan (dengan teknik referensial). Hasil analisis data menunjukkan bahwa ada tiga macam cara pembentukan kata dalam bahasa Talondo, yaitu afiksasi, reduplikasi, dan pemajemukan. Pembentukan kata dengan afiksasi terdiri atas pembentukan kata dengan prefiksasi, konfiksasi, infiksasi, dan sufiksasi. Pembentukan kata dengan reduplikasi terdiri atas reduplikasi murni, reduplikasi sebagian, dan reduplikasi yang berkombinasi dengan afiksasi.
\end{abstract}

Kata kunci: pembentukan kata, bahasa, Talondo

\begin{abstract}
There is Talondo Language in Mamuju, West Sulawesi. The number of speakers is only 400 people (Lewis, 2009:448). The level of vitality is declining (Aritonang, 2014). Languages with a very low number of speakers and a declining level of vitality should be prioritized to be documented. One of the step in documenting a language is by arranging the structure. This research tries to find a small part of the Talondo language structure which is the word formation. Data collection is done by interviewing, recording, listening and writing techniques. Data analysis was done by distributive method (with smallest element description technique, change technique, and expansion technique) and method of padan (with referential technique). The result of data analysis shows that there are three kinds of word formation in Talondo language, those are affixation, reduplication, and compounding. The formation of words with affixation consists of word formation with prefixation, fixation, infixation, and suffixation. Word formation with reduplication consists of pure reduplication, partial reduplication, and reduplication with the combination of affixation.
\end{abstract}

Keywords: word formation, language, Talondo

\section{PENDAHULUAN}

\subsection{Latar Belakang}

Indonesia terdiri atas beratus-ratus etnik dengan kebudayaan dan bahasa masing-masing. Itulah kekayaan Indonesia di samping kekayaan-kekayaan lain yang harus dijaga dan dipertahankan. Sayangnya, ada kekayaan yang kurang terjaga dengan baik. Banyak bahasa daerah yang mulai ditinggalkan penuturnya. Banyak juga bahasa daerah yang terancam punah. Bahkan, ada bahasa daerah yang sudah punah. Beberapa tulisan menginformasikan kurang terjaganya kekayaan Indonesia, yakni kekayaan bahasa daerah.

Collins (2006:3) mengutarakan bahwa dahulu bahasa Amahai di Maluku dituturkan di wilayah Makaraki, Amahai, dan Ruta. Namun, pada tahun 
'70-an, bahasa Amahai hanya dituturkan di Ruta dan hanya dituturkan oleh penutur yang berusia 40 tahun ke atas.

Penelitian yang dilakukan oleh Pusat Penelitian Kemasyarakatan dan Kebudayaan LIPI menunjukkan bahwa anak-anak umur belasan tahun ke bawah di Kampung Lerabaing (Alor) memilih tidak menggunakan bahasa etnik mereka, yaitu bahasa Kui dalam percakapan di rumah maupun dengan tetangganya. Mereka memilih menggunakan bahasa Melayu Alor, baik untuk percakapan di rumah maupun dengan tetangganya, padahal lingkungan tempat tinggal mereka betul-betul hanya dihuni oleh orang Kui (Katubi dan Thung Julan, 2014:40-41).

Patji (2014:4) menyebut bahwa bahasa Kafoa (di Pulau Alor, NTT) merupakan bahasa yang hamper punah. Lauder (2006:5) menginformasikan bahwa di Papua, tercatat tinggal satu orang penutur bahasa Mapia. Dengan demikian, bahasa Mapia dapat dianggap sudah punah karena penutur bahasa Mapia tersebut tidak mempunyai teman untuk berkomunikasi lagi dalam bahasa tersebut. Selain itu, Rumbawer (2006:2-3) mengklasifikasikan Sembilan bahasa di Papua dan Papua Barat sebagai bahasa yang punah total, yaitu (1) bahasa Bapu (Distrik Mamberamo Hilir, Sarmi, Papua), (2) bahasa Dabe (Distrik Pantai Timur, Sarmi, Papua), (3) bahasa Wares (Distrik Bonggo, Sarmi, Papua), (4) bahasa Taworta (Distrik Mamberamo Hulu, Jayapura, Papua), (5) bahasa Waritai (Distrik Mamberamo Hulu, Jayapura, Papua), (6) bahasa Murkim (Distrik Kiwirok, Jayawijaya, Papua), (7) bahasa Walak (Distrik Kelila, Jayawijaya, Papua), (8) bahasa Meoswar (Distrik Ransiki, Manokwari, Papua Barat), dan (9) bahasa Legenyem (Laganyan) (Distrik Waigeo Selatan, Raja Aampat, Papua Barat).

Salah satu program prioritas Badan Pengembangan dan Pembinaan Bahasa ialah konservasi dan revitalisasi bahasa daerah (Sunendar, 2017:1). Beberapa upaya yang dilakukan dalamp elaksanaan program itu ialah penelitian vitalitas atau daya hidup, mendokumentasikan, dan merevitalisasi bahasa-bahasa daerah.
Di Mamuju, Sulawesi Barat ada bahasa Talondo. Jumlah penuturnya 400 orang (Lewis, 2009:448). Menurut Lauder (2006:5), bahasa yang jumlah penuturnya di bawah satu juta jiwa merupakan bahasa yang sangat minim untuk bertahan hidup. Aritonang (2014) telah melakukan penelitian vitalitas bahasa Talondo dan diketahui bahwa vitalitas bahasa Talondo berada pada tingkat "mengalami kemunduran", yaitu tingkat vitalitas antara "aman" dan "terancam punah". Bahasa yang jumlah penuturnya di bawah satu juta jiwa dan tingkat vitalitasnya mengalami kemunduran selayaknya diprioritaskan untuk didokumentasikan.

Salah satu langkah dalam mendokumentasikan suatu bahasa ialah menyusun strukturnya. Upaya penyusunan struktur telah dilakukan. Pada tahun 2014, Palupi melakukan penelitian mengenai fonologi dan leksikon bahasa Talondo (Palupi, 2014). Hasil penelitian Palupi ialah vokal yang meliputi fonem vokal, distribusi fonem vokal, vokal panjang, dan vokal pendek; konsonan yang meliputi fonem konsonan, distribusi fonem konsonan, dan deret konsonan; kosakata dasar Swadesh; dan kosakata budaya dasar yang meliputi (a) kosakata bagian tubuh, (b) kata ganti sapaan dan acuan, (c) istilah kekerabatan, (d) kehidupan desa dan masyarakat, (e) rumah dan bagian-bagiannya, (f) peralatan dan perlengkapan, (g) makanan dan minuman, (h) tanaman, halaman, dan pepohonan), (i) binatang, (j) musim, keadaan alam, benda alam, dan arah, (k) penyakit dan pengobatan, (l) perangai, kata sifat, dan warna, (m) mata pencaharian, (n) pakaian dan perhiasan, (o) permaianan, (p) gerak dan kerja, (q) kata bilangan, dan (r) kata tugas.

\subsection{Masalah}

Berdasarkan latar belakang di atas, rumusan masalah dalam penelitian ini adalah bagaimana pembentukan kata dalam bahasaTalondo.

\subsection{Tujuan}

Penelitian ini berusaha untuk menemukan macammacam pembentukan kata dalam bahasa Talondo. Hasil penelitian ini menjadi bagian dari upaya penyusunan struktur bahasa Talondo. 


\subsection{Metode}

Pengumpulan data dilakukan di Desa Talondo, Kecamatan Bonehau, Kabupaten Mamuju, Sulawesi Barat. Teknik pengumpulan data yang digunakan ialah teknik wawancara, teknik rekam, serta teknik simak dan catat. Teknik simak ini dapat disejajarkan dengan teknik observasi dalam ilmu sosial (Sudaryanto, 1993:133).

Metode yang digunakan untuk menganalisis data dalam penelitian ini ialah metode distribusional dan metode padan. Metode distribusional ialah metode analisis linguistik yang dikembangkan oleh linguistik strukturalisme model Amerika (Subroto, 1992:63). Sudaryanto menyebut metode ini sebagai metode agih (1993). Selanjutnya Subroto membagi metode ini menjadi teknik urai unsur terkecil, teknik urai unsur langsung, teknik oposisi, teknik pergantian, teknik perluasan, teknik pelepasan, teknik penyisipan, teknik pembalikan urutan, dan teknik parafrasis. Namun, karena penelitian ini ialah penelitian morfologi, teknik yang dianggap tepat oleh peneliti dalam analisis data ialah teknik urai unsur terkecil, teknik pergantian, dan teknik ekspansi.

Subroto (1992:55-56) mengatakan bahwa metode padan sering juga disebut dengan metode identitas yaitu metode yang dipakai untuk menentukan identitas suatu satuan lingual tertentu dengan alat penentu di luar bahasa, terlepas dari bahasa, dan tidak menjadi bagian dari bahasa yang bersangkutan. Lebih lanjut, Sudaryanto membagi metode ini menjadi lima (Sudaryanto, 1993:13-14) yaitu (1) teknik referensial, alat penentunya ialah kenyataan yang ditunjuk oleh bahasa atau referent bahasa; (2) teknik fonetis artikulatoris, alat penentunya organ pembentuk bahasa atau organ wicara; (3) teknik translational, alat penentunya bahasa lain; (4) teknik ortografi, alat penentunya pengawet bahasa, perekam atau tulisan; dan (5) teknik pragmatis, alat penentunya ialah mitra wicara. Dari kelima teknik tersebut, penelitian ini menggunakan satu teknik saja, yaitu teknik referensial.

\section{LANDASAN TEORI}

Penelitian ini menggunakan ancangan strukturalisme, yaitu meneliti dan memerikan serta menerangkan segi-segi tertentu mengenai struktur bahasa berdasarkan fakta yang dijumpai dalam pertuturan (Subroto, 1992:32). Dalam bidang morfologi, organisasi atau model morfologi struktural terdiri atas empat komponen, yaitu (1) daftar morfem, (2) pembentukan kata, (3) proses morfofonogis, dan (4) kamus (Ba'dulu, 2010:1617).

Ba'dulu (2010:21-22) menerangkan pembentukan kata yang meliputi afiksasi dan pemajemukan. Sementara itu, Verhar (2006:98 - 99 dan 151-156) menerangkan jenis pembentukan kata yang lebih lengkap, yaitu meliputi afiksasi, pengklitikaan, reduplikasi, dan komposisi serta penjelasan yang lebih lengkap juga.

\section{HASIL DAN PEMBAHASAN}

Berdasarkan analisis data, ada tiga macam cara pembentukan kata dalam bahasa Talondo, yaitu afiksasi, reduplikasi, dan pemajemukan.

\subsection{Pembentukan Kata dengan Afiksasi}

Afiksasi dalam bahasa Talondo terdiri atas prefiksasi, infiksasi, konfiksasi, dan sufiksasi. Uraiannya ialah sebagai berikut.

\subsubsection{Pembentukan Kata dengan Prefiksasi 3.1.1.1 Pembentukan Kata dengan Prefiks maN-}

Berikut ini beberapa contohnya.

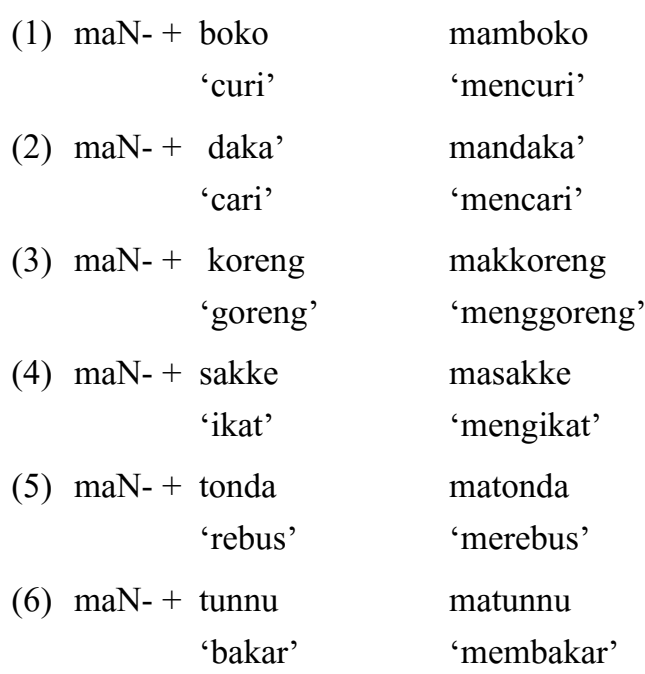




\subsubsection{Pembentukan Kata dengan}

Prefiks mak-

Berikut ini beberapa contohnya.
(7) mak- + tanung $\rightarrow$ maktanung
'tenun' 'menenun'
(8) mak- + dondo $\rightarrow$ makdondo 'lari' 'berlari'
(9) mak- + kowek $\rightarrow$ makkowek 'buai' 'menidurkan'

\subsubsection{Pembentukan Kata dengan Prefiks mu-}

Berikut ini data yang ditemukan.

$$
\begin{array}{lll}
\text { (10) mu- }+\begin{array}{l}
\text { langi } \\
\text { 'renang' }
\end{array} & \rightarrow & \begin{array}{l}
\text { mulangi } \\
\text { 'berenang' }
\end{array} \\
\text { (11) mu- }+ & \begin{array}{l}
\text { asu } \\
\text { 'anjing' }
\end{array}
\end{array} \rightarrow \begin{aligned}
& \text { muasu } \\
& \text { 'berburu' }
\end{aligned}
$$

\subsubsection{Pembentukan Kata dengan Prefiks $k i$ -}

Berikut ini data yang ditemukan.

$\begin{array}{lll}\text { (12) ki- }+ & \begin{array}{l}\text { anak } \\ \text { 'anak' }\end{array}\end{array} \rightarrow \begin{aligned} & \text { kianak } \\ & \text { 'beranak, melahirkan' } \\ & \text { (13) ki- }+ \\ & \begin{array}{l}\text { hulu } \\ \text { 'bulu' }\end{array}\end{aligned} \rightarrow \begin{aligned} & \text { kihulu } \\ & \text { 'berbulu' }\end{aligned}$

Berikut ini data yang ditemukan.
$\begin{aligned} & \text { (14) ti- }+ \text { kudu } \\ & \text { 'ludah' }\end{aligned}$
(15) ti-

$\begin{array}{ll}\text { lua' } & \rightarrow \quad \text { tilua' } \\ \text { 'muntah' } & \text { 'muntah' }\end{array}$

\subsubsection{Pembentukan Kata dengan Prefiks pa-}

Berikut ini beberapa contohnya.

$\begin{array}{llll}\text { (16) pa-+ } & \begin{array}{l}\text { bikkung } \\ \text { 'cangkul' }\end{array} & \rightarrow & \begin{array}{l}\text { pabikkung } \\ \text { 'pencangkul' }\end{array} \\ \text { (17) pa-+ } & \begin{array}{l}\text { seppo } \\ \text { 'tebang' }\end{array} & \begin{array}{l}\rightarrow \\ \text { 'penebang' }\end{array} \\ \text { (18) pa-+ } & \begin{array}{l}\text { uma } \\ \text { 'kebun' }\end{array} & \text { 'petani, pekebun' }\end{array}$

\subsubsection{Pembentukan Kata dengan Prefiks pi-}

Berikut ini beberapa contohnya.
(19) pi- + penda $\rightarrow$ pipenda 'pukul' 'pemukul'
(20) pi- + tutu $\rightarrow$ pitutu 'gerus' 'penggerus'

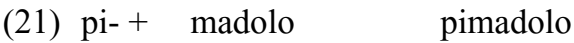 'garis' 'penggaris'
(22) $\mathrm{pi}-+$ timba $\rightarrow$ pitimba 'timba' '(alat) pengambil air, gayung'

\subsubsection{Pembentukan Kata dengan

\begin{tabular}{|c|c|c|c|c|}
\hline (23) & i- + & boko & $\rightarrow$ & iboko \\
\hline & & 'curi' & & 'dicuri' \\
\hline (24) & $\mathrm{i}-+$ & daka' & $\rightarrow$ & idaka' \\
\hline & & 'cari' & & 'dicari' \\
\hline (25) & $\mathrm{i}-+$ & koreng & $\rightarrow$ & ikkoreng \\
\hline & & 'goreng' & & 'digoreng' \\
\hline (26) & $\mathrm{i}-+$ & sakke & $\rightarrow$ & isakke \\
\hline & & 'ikat' & & 'diikat' \\
\hline
\end{tabular} Prefiks $i-$}

Berikut ini beberapa contohnya.

\subsubsection{Pembentukan Kata dengan Infiks $-u m$}

Berikut ini data yang ditemukan.

\section{(27) likka + -um $\rightarrow$ lumikka 'jalan' 'berjalan' \\ 3.1.2 Pembentukan Kata dengan Konfiksasi}

Berikut ini data yang ditemukan.
(28) koreng + pa-ang $\rightarrow$ pakkorengang 'goreng' 'penggorengan'
(29) tunnu + pa-ang $\rightarrow$ patunnuang 'bakar' 'pembakaran'




\subsubsection{Pembentukan Kata dengan Sufiksasi}

\subsubsection{Pembentukan Kata} dengan Sufiks-ang

Berikut ini beberapa contohnya.

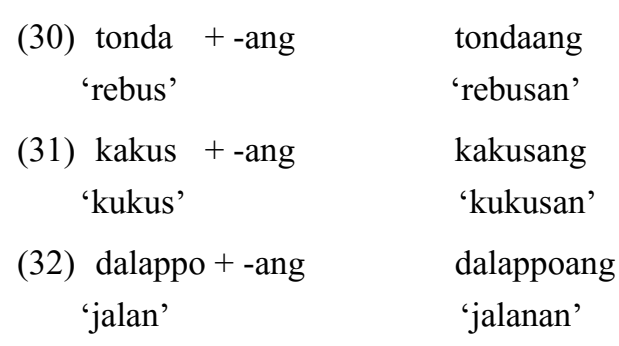

\subsubsection{Pembentukan Kata dengan Sufiks -akking}

Berikut ini beberapa contohnya.

(33) Mangngalli + -akking $\rightarrow \begin{aligned} & \text { mangngalliakking } \\ & \text { 'membeli } \\ & \text { 'membelikan }\end{aligned}$
$\begin{gathered}\text { (34) ialli + -akking } \\ \text { 'dibeli }\end{gathered}$
$\begin{gathered}\text { ialliakking } \\ \text { 'dibelikan' }\end{gathered}$
'menjual' ma'ballu + -akking $\rightarrow \begin{aligned} & \text { ma'balluakking } \\ & \text { 'menjualkan' }\end{aligned}$
(36) Iballu' + -akking $\rightarrow$ iballuaking
'dijual'

\subsection{Pembentukan Kata dengan Reduplikasi}

\subsubsection{Reduplikasi Murni}

Berikut ini beberapa contohnya.
(37) isi-isi $\quad \rightarrow \quad$ isi 'gigi-gigi' 'gigi'
(38) mande-mande $\rightarrow \quad$ mande 'makan-makan' 'makan'
(39) bela-bela $\rightarrow$ bela
'kebun-kebun (kecil)' 'kebun'
(40) sala-sala $\rightarrow$ sala 'salah-salah' 'salah'

\subsubsection{Reduplikasi sebagian}

Berikut ini data yang ditemukan.
(41) malea-lea
$\rightarrow \quad$ malea
'kemerah-merahan'
'merah'
(42) bakahu-kahu; babakahu-kahu $\rightarrow$ bakahu 'baru-baru'

\subsubsection{Reduplikasi yang Berkombinasi dengan Afiksasi \\ 3.2.3.1 Reduplikasi dengan sufiks maN-}

Berikut ini beberapa contohnya.

\begin{tabular}{|c|c|c|c|}
\hline (43) & mabusa-busa & $\rightarrow$ & busa \\
\hline & 'putih-putih' & & 'putih' \\
\hline 44) & maningo-ningo & $\longrightarrow$ & ningo \\
\hline & 'bermain-main' & & 'main' \\
\hline$(45)$ & mahengi-hengi & $\longrightarrow$ & hengi \\
\hline & 'kehitam-hitaman & & hitam \\
\hline 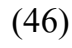 & mallapi-lapi & $\rightarrow$ & lapi \\
\hline & 'berlapis-lapis' & & 'lapis' \\
\hline
\end{tabular}

\subsubsection{Reduplikasi dengan Sufiks mak-}

Berikut ini data yang ditemukan.
(47) maksule -sule $\rightarrow \quad$ sule 'bolak-balik' 'balik'
(48) makdondo-dondo $\rightarrow$ dondo 'berlari-lari kecil' 'lari'

\subsubsection{Reduplikasi dengan Infiks -} um-

Berikut ini data yang ditemukan.
(49) lumikka-mikka $\rightarrow \quad$ mikka 'berjalan-jalan' 'jalan'

\subsubsection{Reduplikasi dengan Prefiks si-}

Berikut ini beberapa contohnya.
(50) sidanggu-danggu $\rightarrow$ danggu 'saling meninju' 'tinju'
(51) sipenda-penda $\rightarrow$ penda 'saling memukul 'pukul menggunakan alat' menggunakan alat'
(52) siala-ala $\rightarrow$ ala 'berpukul-pukulan, 'pukul' saling memukul ${ }^{\star}$

\subsubsection{Reduplikasi dengan Prefiks i-}

Berikut ini data yang ditemukan.
(53) isorong-sorong
sorong
'didorong-dorong'
'dorong' 


\subsubsection{Reduplikasi dengan Prefiks ka-}

Berikut ini data yang ditemukan.

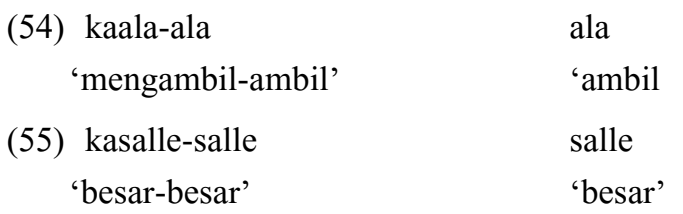

\subsubsection{Reduplikasi sebagian dengan Sufiks -i}

Berikut ini data yang ditemukan.

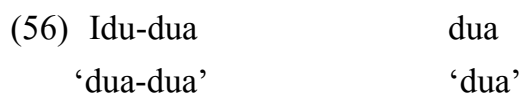

\subsubsection{Reduplikasi dengan Sufiks - ang}

Berikut ini data yang ditemukan.

$$
\begin{array}{lll}
\text { (57) pihi-pihiang } & \rightarrow & \text { pihi } \\
\text { 'rumput-rumputan' } & & \text { 'rumput' }
\end{array}
$$

\subsubsection{Reduplikasi dengan Konfks pa-ang}

Berikut ini data yang ditemukan.

$$
\begin{array}{cll}
\text { (58) pangande-andeang } & \rightarrow & \begin{array}{l}
\text { ande } \\
\text { 'lauk-pauk' }
\end{array}
\end{array}
$$

\subsection{Pembentukan Kata dengan Pemajemukan}

Berikut ini beberapa contoh hasil pembentukan kata dengan pemajemukan.

(61) mata talinga 'mata telinga'

(62) mabanda pinaha 'berat hati'
(63) maidua pinaha 'hati bercabang'

(64) mapia pikki 'pikiran sehat'

(65) banua ada' 'rumah adat'

(66) letong ada' 'rumah adat'

(67) maidua paleppa 'bersilat lidah'

(68) mengang mande 'meja makan'

(69) roteng toma'pakulli 'rumah sakit'

(70) tambi pindioang 'kamar mandi'

(71) kulla' kasalle 'hari raya'

(72) anak poho 'anak tiri'

\section{SIMPULAN}

Ada tiga macam cara pembentukan kata dalam bahasa Talondo, yaitu afiksasi, reduplikasi, dan pemajemukan. Pembentukan kata dengan afiksasi terdiri atas pembentukan kata dengan prefiks $\mathrm{maN}$-, dengan prefiks mak-, dengan prefiks $m u$-, dengan prefiks $k i$, dengan prefiks $t i-$, dengan prefiks $p a-$, dengan prefiks $p i-$, dengan prefiks $i-$, dengan konfiks pa-ang, dengan sufiks -ang, dengan sufiks akking, dan dengan infiks -um. Pembentukan kata dengan reduplikasi terdiri atas reduplikasi murni dan reduplikasi yang berkombinasi dengan afiksasi.

\section{UCAPAN TERIMA KASIH}

Penelitian ini dari tahap awal sampai akhir tidak lepas dari kepercayaan, dukungan, dan kebaikankebaikan lain dari banyak pihak. Sehubungan dengan itu, penulis mengucapkan terima kasih kepada pimpinan Badan Pengembangan dan Pembinaan Bahasa serta staf yang telah memberikan kepercayaan dan dukungan. Penulis juga mengucapkan terima kasih kepada Sdr. M. Ridwan yang membantu dalam pengumpulan data.

\section{DAFTAR PUSTAKA}

Aritonang, Buha. 2014. "Bahasa Terancam Punah: Kajian Vitalitas Bahasa Talondo di Sulawesi Barat”, Laporan Penelitian Badan Pengembangan dan Pembinaan Bahasa.

Ba’dulu, Abdul Muisdan Herman. 2010. Morfosintaksis. Jakarta: Rineka Cipta.

Collins, James T. 2006. “Bahasa Daerah yang Terancam Punah: Tinjauan di Maluku dan Kalimantan”, Makalah Seminar Pelestarian Bahasa Daerah, Pusat Bahasa, Departemen Pendidikan dan Kebudayaan, 9 Desember. 
Katubi dan Thung Julan. 2014. Vitalitas Etnolinguistik dan Agen Pemertahanan Bahasa Kui di Alor, Nusa Tenggara Timur. Jakarta: PT Gading Inti Prima.

Lauder, Multamia R.M.T. 2006. "Revitalisasi Bahasa Minoritas”, Makalah Seminar Pelestarian Bahasa Daerah, Pusat Bahasa, Departemen Pendidikan dan Kebudayaan, 9 Desember

Lewis, M. Paul (Editor). 2009. Ethnologue Languages of the World. Dallas: SIL International.

Patji, Abdul Rachman (Editor). 2014. Bahasa, Kebudayaan, dan Pandangan tentang Kebahasaan Masyarakat Etnik (Lokal) Kafoa di Alor, Nusa Tenggara Timur. Jakarta: LIPI Press.

Palupi, Dian, Marida G. Siregar, dan Buha Aritonang. 2014. "Bahasa Terancam Punah: Fonologi dan Leksikon Bahasa Talondo”, Laporan Penelitian Badan Pengembangan dan Pembinaan Bahasa.

Rumbrawer, Frans. 2006. "Renungan Singkat tentang Kepunahan Aneka Bahasa Daerah di Tanah Papua", Makalah Seminar Pelestarian Bahasa Daerah, Pusat Bahasa, Departemen Pendidikan dan Kebudayaan, 9 Desember.

Subroto, D. Edi. 1992. Pengantar Metode Penelitian Linguistik Struktural. Surakarta: Sebelas Maret University Press.

Sudaryanto. 1993. Metode dan Aneka Teknik Analisis Bahasa. Yogyakarta: Duta Wacana University Press.

Sunendar, Dadang. 2017. "Potensi Bahasa Daerah sebagai Pemerkaya Bahasa Indonesia”, Makalah Seminar Nasianal Bahasa Ibu, Badan Pengembangan dan Pembinaan Bahasa, 22 Februari.

Verhar, J.W.M. 2006. Asas-Asas Linguistik Umum. Yogyakarta: Gadjah Mada University Press. 
Mardi Nugroho: Pembentukan Kata dalam Bahasa Talondo 